\title{
Toxicity and genotoxicity of wastewater from gasoline stations
}

\author{
Cynthia R. Oliveira-Martins ${ }^{1}$ and Cesar K. Grisolia ${ }^{2}$ \\ ${ }^{1}$ Agência Nacional do Petróleo, Brasília, DF, Brazil. \\ ${ }^{2}$ Departamento de Genética e Morfologia, Instituto de Ciências Biológicas, Universidade de Brasília, \\ Brasilia, DF, Brazil.
}

\begin{abstract}
The toxicity and genotoxicity of wastewater from eight gasoline stations in Brasília, Brazil's capital city, was studied by assessing chromosomal aberrations, chromosomal malsegregation and the mitotic index in Allium cepa root cells, and the occurrence of micronucleus and nuclear abnormalities in peripheral erythrocytes of tilapia fish (Oreochromis niloticus). The content of gasoline station effluents was also analyzed based on several physico-chemical parameters. None of the wastewater samples was genotoxic to $A$. cepa root cells, although cell proliferation was significantly inhibited, especially at the highest concentrations. Likewise, no micronuclei were observed in $O$. niloticus peripheral erythrocytes, even after exposure to high concentrations, but there was an increase in the number of nuclear abnormalities and fish mortality. These results show that although the effluent from gasoline stations is processed by an oil/water separation system before being discharged into the main sewage system, the wastewater still contains toxic compounds.
\end{abstract}

Key words: Allium cepa, chromosomal aberrations, gas station, micronucleus, Oreochromis niloticus.

Received: January 28, 2009; Accepted: June 9, 2009.

Harmful effluents discharged into the environment have the potential to reach waterbodies and disturb aquatic ecosystems. Water contamination by gasoline residues and other petroleum derivatives is of particular concern because of the presence of polycyclic aromatic hydrocarbons (PAHs) that are mutagenic and carcinogenic (Cooke and Dennis, 1985; Hertel et al., 1998). The genotoxicity of contaminated water is frequently assessed by using onion (Allium cepa) root cells and various fish species that provide rapid, sensitive assays for detecting genetic alterations such as micronuclei, chromosomal breaks, DNA lesion (comet assay), nuclear abnormalities and changes in the mitotic index in proliferating cells (Rank and Nielsen, 1993; Hayashi et al., 1998; Belfiore and Anderson, 2001).

Many studies have examined the risk of genotoxicity in humans, especially gasoline station attendants, exposed to petroleum derivative compounds (Santos-Mello and Cavalcante, 1992; Carere et al., 1995; Bukvic et al., 1998; Çelik et al., 2003; Çelik and Akbas 2005; Benites et al., 2006). In contrast, there are no data on the genotoxicity of wastewater from gasoline stations. In this study, we examined the genotoxicity of wastewater from eight gasoline stations in Brasília, Brazil's capital city. We used A. cepa root cells to screen for chromosomal aberrations, chromo-

Send correspondence to Cesar Koppe Grisolia. Departamento de Genética e Morfologia, Instituto de Ciências Biológicas, Universidade de Brasília, 70910-900 Brasília, DF, Brazil. E-mail: grisolia@unb.br. somal malsegregation and inhibition of the mitotic index, and peripheral erythrocytes of fish (Oreochromis niloticus; tilapia) to screen for micronuclei and nuclear abnormalities. As shown elsewhere (Grisolia and Cordeiro, 2000; Hoshima et al., 2008), O. niloticus is a suitable species for in situ biomonitoring of mutagens and genotoxic compounds in effluent discharged by petroleum refineries.

As stipulated by District Acts numbers 5631 (November $27^{\text {th }}, 1980$ ) and 26590 (February $23^{\text {th }}, 2006$ ), all gasoline stations must have an effluent receptor system to separate suspended solids, oil and grease from wastewater before it goes to sewage pipelines and district wastewater treatment plants. In such a scheme, all types of petroleum residues resulting from gasoline station activities go to a system of four tanks involved in oil/water separation (Figure 1). Oil is recovered for recycling and the final effluent is discharged into the domestic sewage system. In this work, effluent samples of $20 \mathrm{~L}$ for physico-chemical and biological analyses were collected from the inspection tanks (Figure 1) of eight gasoline stations. The samples were analyzed according to criteria of the Brazilian Association of Technical Standards (ABNT - NBR 9800). Oil and grease were analyzed after extraction with organic solvents in a soxhlet apparatus. For each effluent sample collected, standard physico-chemical parameters were measured, including $\mathrm{pH}$, biochemical oxygen demand (BOD), chemical oxygen demand (COD) and total solids in suspension. Benzene, toluene and xylene were analyzed by gas chromatog- 


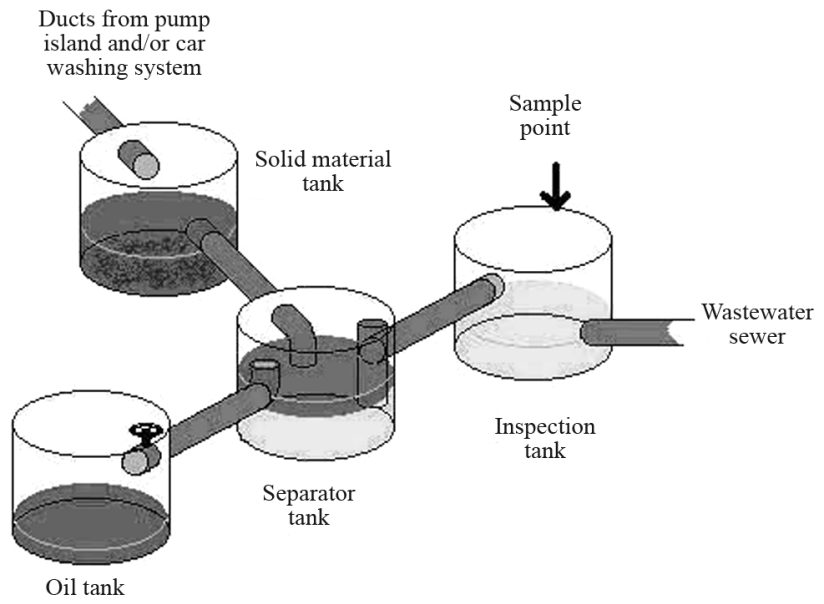

Figure 1 - Receptor system for separating oil from water in gas station wastewater.

raphy (Hewlett Packard HP 6890 gas chromatograph). Phenols, benzene, toluene and xylene were detected by spectrophotometry (Shimadzu UV420 UV-Vis spectrophotometer). Metals were detected by atomic-absorption spectrometry (Variant FS220 spectrometer).

The $A$. cepa test to screen for genotoxicity was done as described by Rank and Nielsen (1993). Commercial onion bulbs that had not been treated with growth inhibitors were obtained from organic growers. Ten onions were used for each dilution tested. Prior to the genotoxicity test, growth inhibition tests were done for each wastewater sample to determine their toxicity. Wastewater was diluted $10 \%$ and $50 \%$ and the genotoxicity tests were done for $48 \mathrm{~h}$, during which the treated cell suspensions were shaken continuously in a horizontal shaker. Good quality, filtered, dechlorinated tap water ( $\mathrm{pH}$ 7.0) was used as a negative control and for dilution of the effluents. At the end of exposure, five or six root tips from each bulb were prepared for microscopic examination. One hundred metaphase - telophase cells were analyzed per bulb (total of 1000 cells per treatment). The root tips were fixed and macerated in $45 \%$ acetic acid: $1 \mathrm{~N} \mathrm{HCl}(9: 1, \mathrm{v} / \mathrm{v})$ at $50{ }^{\circ} \mathrm{C}$ for $5 \mathrm{~min}$, followed by squashing in $2 \%$ orcein stain in $45 \%$ acetic acid. The slides were coded and stored in a freezer and examined within one week by an individual unaware of their identification. The root tip metaphase or anaphase cells were examined and classified as bridges, fragments, and lagging chromosomes. The mitotic index was determined by counting the number of mitotic cells (all stages) in 1000 cells.

Genotoxicity in fish was studied in aquaria containing $30 \mathrm{~L}$ of continuously aerated wastewater diluted $10 \%$ and $50 \%$. The fish were maintained $24 \pm 2{ }^{\circ} \mathrm{C}$ and were not fed during the exposure to wastewater. The ammonium level in the water was constantly monitored, and the conductivity and $\mathrm{pH}$ were kept at $500 \mu \mathrm{S}$ and 7.2 , respectively. Ten tilapias (O. niloticus; $30 \pm 5 \mathrm{~g}$, mean $\pm \mathrm{SD}$ ) from the same batch (five per aquarium) were used for each treatment during which the fish were exposed to the desired dilution for $96 \mathrm{~h}$. Filtered, dechlorinated tap water was used as negative control. Peripheral blood was obtained by cardiac puncture with a heparinized syringe and immediately smeared. After fixation in ethanol for $15 \mathrm{~min}$, the slides were left to air-dry and then stained with 5\% Giemsa. Three thousand erythrocytes were examined for each fish at a magnification of 1000x. The nuclear abnormalities proposed by Hooftman and Raat (1982) were used as a biomarker of cytotoxicity. The nuclei were classified as blebbed, lobed, notched or binucleated. The percentage of cells with heteromorphic nuclei was determined based on an analysis of 1000 cells per fish. The frequencies of micronuclei and nuclear abnormalities were calculated from the same microscope slide.

The results were expressed as the mean $\pm \mathrm{SD}$. The chromosomal aberrations and changes in mitotic index in the $A$. cepa experiments were analyzed by using Students $t$-test for paired samples. The micronuclei and nuclear abnormality results with $O$. niloticus were analyzed with the non-parametric Mann Whitney- $U$ test. In all cases a value of $p<0.05$ indicated significance. All analyses were done using SigmaStat software, version 3.5 (Jandel Scientific).

Comparison of the physico-chemical parameters of the crude effluent in the sand tank and final effluent in the inspection tank showed that the oil/water separation system was efficient, but that it did not completely remove all of the toxic compounds in wastewater (Table 1). The levels of

Table 1 - Comparison of the physico-chemical parameters of samples obtained from the two main tanks of a gas station wastewater receptor system.

\begin{tabular}{lcc}
\hline & $\begin{array}{c}\text { Sand tank } \\
\text { (crude effluent) }\end{array}$ & $\begin{array}{c}\text { Inspection tank } \\
\text { (final effluent) }\end{array}$ \\
\hline $\mathrm{pH}$ & 6 & 6 \\
$\mathrm{COD}(\mathrm{mg} / \mathrm{L})$ & 404 & 299 \\
$\mathrm{BOD}(\mathrm{mg} / \mathrm{L})$ & 180 & 190 \\
Oil and grease $(\mathrm{mg} / \mathrm{L})$ & 30 & 18 \\
Suspended solids $(\mathrm{mg} / \mathrm{L})$ & 34 & 17 \\
Volatile suspended solids $(\mathrm{mg} / \mathrm{L})$ & 17 & 10 \\
Fixed suspended solids $(\mathrm{mg} / \mathrm{L})$ & 17 & 7 \\
Benzene $(\mu \mathrm{g} / \mathrm{L})$ & 41.8 & 23.7 \\
Toluene $(\mu \mathrm{g} / \mathrm{L})$ & 291.5 & 152.4 \\
Ethylbenzene $(\mu \mathrm{g} / \mathrm{L})$ & 90.3 & 34.0 \\
Xylene $(\mu \mathrm{g} / \mathrm{L})$ & 671.4 & 277.1 \\
Phenols $(\mathrm{mg} / \mathrm{L})$ & 0.679 & 0.217 \\
Iron $(\mathrm{mg} / \mathrm{L})$ & $\mathrm{ND}$ & $\mathrm{ND}$ \\
Copper $(\mathrm{mg} / \mathrm{L})$ & 0.027 & 0.007 \\
Nickel $(\mathrm{mg} / \mathrm{L})$ & 0.105 & $\mathrm{ND}$ \\
Zinc $(\mathrm{mg} / \mathrm{L})$ & 0.005 & 0.041 \\
\hline
\end{tabular}

$\mathrm{ND}$ - not detected.

Solid material tank from Figure 1 correspond to sand tank. 
Table 2 - Chromosomal damage and proliferation of A. cepa root tip cells exposed to different concentrations of gas station wastewater.

\begin{tabular}{|c|c|c|c|c|c|c|c|c|}
\hline \multicolumn{2}{|c|}{ Samples } & \multicolumn{3}{|c|}{ Chromosomal aberration (\%) } & \multirow{2}{*}{$\begin{array}{c}\text { Total of } \\
\text { damaged cells }\end{array}$} & \multirow[t]{2}{*}{$\mathrm{p}$} & \multirow[t]{2}{*}{ Mitotic index (\%) } & \multirow[t]{2}{*}{$\mathrm{p}$} \\
\hline & & Bridges & Fragments & $\begin{array}{c}\text { Chromosome } \\
\text { lagging }\end{array}$ & & & & \\
\hline \multirow[t]{3}{*}{1} & Control & $0.05 \pm 0.02$ & $0.05 \pm 0.03$ & $0.00 \pm 0.00$ & $0.10 \pm 0.15$ & - & $8.83 \pm 1.16$ & - \\
\hline & $10 \%$ & 0.00 & $0.10 \pm 0.32$ & 0.00 & $0.10 \pm 0.32$ & 0.0732 & $8.89 \pm 1.94$ & 0.8203 \\
\hline & $50 \%$ & 0.00 & $0.15 \pm 0.67$ & $0.10 \pm 0.32$ & $0.25 \pm 0.40$ & 0.4345 & $7.56 \pm 1.70$ & 0.1038 \\
\hline \multirow[t]{2}{*}{2} & Control & 0.00 & 0.00 & 0.00 & 0.00 & - & $10.75 \pm 2.47$ & - \\
\hline & $10 \%$ & $0.12 \pm 0.67$ & $0.05 \pm 0.48$ & $0.10 \pm 0.32$ & $0.27 \pm 0.87$ & 0.0303 & $3.12 \pm 1.51$ & $0.0041^{*}$ \\
\hline \multirow[t]{3}{*}{3} & Control & 0.00 & 0.00 & $0.10 \pm 0.32$ & $0.10 \pm 0.32$ & - & $9.47 \pm 2.89$ & - \\
\hline & $10 \%$ & 0.00 & 0.00 & $0.10 \pm 0.32$ & $0.10 \pm 0.32$ & 0.5032 & $7.80 \pm 1.77$ & 0.1734 \\
\hline & $50 \%$ & 0.00 & 0.00 & $0.14 \pm 0.12$ & $0.14 \pm 0.12$ & 0.5270 & $2.58 \pm 0.79$ & $0.0046^{*}$ \\
\hline \multirow[t]{3}{*}{4} & Control & $0.10 \pm 0.32$ & $0.05 \pm 0.12$ & 0.00 & $0.15 \pm 0.50$ & - & $9.80 \pm 2.96$ & - \\
\hline & $10 \%$ & $0.10 \pm 0.32$ & $0.10 \pm 0.32$ & $0.10 \pm 0.32$ & $0.30 \pm 0.67$ & 1.0000 & $11.27 \pm 2.14$ & 0.1433 \\
\hline & $50 \%$ & $0.06 \pm 0.42$ & $0.12 \pm 0.42$ & $0.02 \pm 0.20$ & $0.20 \pm 0.71$ & 0.3986 & $11.07 \pm 1.52$ & 0.1647 \\
\hline \multirow[t]{3}{*}{5} & Control & 0.00 & 0.00 & 0.00 & 0.00 & - & $10.43 \pm 3.92$ & - \\
\hline & $10 \%$ & 0.00 & $0.18 \pm 0.23$ & 0.00 & $0.18 \pm 0.23$ & 0.1256 & $4.23 \pm 2.80$ & $0.0048^{*}$ \\
\hline & $50 \%$ & 0.00 & 0.00 & 0.00 & 0.00 & 0.0000 & $1.04 \pm 0.49$ & $0.0006^{*}$ \\
\hline \multirow[t]{3}{*}{6} & Control & 0.00 & $0.10 \pm 0.32$ & $0.02 \pm 0.42$ & $0.12 \pm 0.35$ & - & $10.43 \pm 3.32$ & - \\
\hline & $10 \%$ & 0.00 & 0.00 & $0.10 \pm 0.32$ & $0.10 \pm 0.32$ & 0.2758 & $10.57 \pm 3.69$ & 0.7623 \\
\hline & $50 \%$ & $0.08 \pm 0.30$ & $0.18 \pm 0.13$ & $0.00 \pm 0.00$ & $0.26 \pm 0.22$ & 0.8420 & $4.01 \pm 1.60$ & $0.0112 *$ \\
\hline \multirow[t]{3}{*}{7} & Control & 0.00 & 0.00 & 0.00 & 0.00 & - & $14.08 \pm 1.40$ & - \\
\hline & $10 \%$ & $0.11 \pm 0.33$ & $0.11 \pm 0.33$ & 0.00 & $0.22 \pm 0.67$ & 0.0820 & $4.31 \pm 2.12$ & $0.0128 *$ \\
\hline & $50 \%$ & $0.14 \pm 0.60$ & $0.10 \pm 0.52$ & $0.17 \pm 0.41$ & $0.41 \pm 0.97$ & 0.0538 & $5.12 \pm 1.84$ & $0.0199 *$ \\
\hline \multirow[t]{3}{*}{8} & Control & $0.02 \pm 0.42$ & $0.05 \pm 0.63$ & $0.10 \pm 0.95$ & $0.17 \pm 0.87$ & - & $12.32 \pm 3.44$ & - \\
\hline & $10 \%$ & 0.00 & $0.10 \pm 0.32$ & $0.10 \pm 0.32$ & $0.20 \pm 0.42$ & 0.4853 & $9.65 \pm 3.74$ & 0.6968 \\
\hline & $50 \%$ & 0.00 & 0.00 & $0.14 \pm 0.38$ & $0.14 \pm 0.38$ & 0.3930 & $2.57 \pm 0.66$ & $0.0065^{*}$ \\
\hline
\end{tabular}

*Significantly different $(\mathrm{p}<0.05)$ from the control.

oil and grease were lower than reference values, indicating that the system partially removed these compounds, whereas benzene, toluene, xylene and phenols were still present in some wastewater samples. The percentage reductions for several important parameters were: COD 26\%, oil and grease $6.7 \%$, total suspended solids $50 \%$, volatile suspended solids $41 \%$, fixed suspended solids $59 \%$, benzene $43 \%$, toluene $47.7 \%$, ethyl-benzene $62.4 \%$ and phenols $68 \%$.

No chromosomal aberrations were observed with any of the samples in the genotoxicity assays with A. серa (Table 2). However, cell proliferation was significantly inhibited, especially at the highest concentrations tested. There was also a significant decrease in the mitotic index of root tip cells with samples $2,3,5,6,7$ and 8 . Sample number 2 was the most toxic since it completely inhibited cell proliferation at a concentration of $50 \%$. No micronuclei were observed in fish peripheral erythrocytes at any of the concentrations tested (Table 3). However, samples 2, 3, 6, 7 and 8 significantly increased the number of nuclear abnormalities in these cells (Table 4). Samples 2, 7 and 8 were tested only at a concentration of $10 \%$ because a greater concentration $(50 \%)$ caused high mortality in the first $48 \mathrm{~h}$ of exposure.

Comparison of the values for the various parameters used to monitor the sand tanks and inspection tanks showed that although the oil/water separation system was efficient in reducing the levels of toxic compounds it did not completely remove the compounds that posed environmental risks (Table 1). The level of heavy metals, such as iron, copper, nickel and zinc, in the inspection tanks was considered insignificant. The results for the quantitative analysis of physico-chemical parameters were generally confirmed by the cyotoxicity assay in $A$. cepa root tip cells, which showed strong inhibition of cell proliferation.

The efficiency of the oil/water separation system is directly related to its regular maintenance. Based on the results obtained here, the oil/water separation systems of gasoline stations 1 and 4 showed poor maintenance because of their higher level of suspended solids. However, although these systems were saturated, their wastewater was not 
Table 3 - Occurrence of micronuclei and nuclear abnormalities in peripheral erythrocytes of $O$. niloticus exposed to gas station wastewater.

\begin{tabular}{lccccc}
\hline Samples & Dilution (\%) & Micronuclei per 3000 cells & $\mathrm{p}$ & Nuclear abnormalities per 1000 cells & $\mathrm{p}$ \\
\hline Control & - & $1.10 \pm 1.37$ & & $69.2 \pm 32.7$ & 0.8879 \\
\hline 1 & 10 & $6.82 \pm 4.69$ & 0.3012 & $68.6 \pm 31.8$ & 0.2311 \\
\hline 2 & 50 & $2.00 \pm 1.90$ & 0.1903 & $88.6 \pm 45.4$ & $0.0211^{*}$ \\
\hline 3 & 10 & $0.45 \pm 0.82$ & 0.6500 & $188.6 \pm 13.8$ & $0.0372^{*}$ \\
& 10 & $0.58 \pm 0.67$ & 0.5653 & $115.3 \pm 41.1$ & $0.0163^{*}$ \\
\hline 4 & 50 & $0.20 \pm 0.42$ & 0.9000 & $174.9 \pm 23.0$ & 0.2566 \\
& 10 & $3.70 \pm 2.63$ & 0.1045 & $89.6 \pm 42.7$ & 0.4725 \\
\hline 5 & 50 & $3.40 \pm 1.90$ & 0.1090 & $60.1 \pm 19.7$ & 0.3471 \\
& 10 & $3.90 \pm 1.73$ & 0.0924 & $50.8 \pm 17.1$ & 0.2315 \\
\hline 6 & 50 & $2.20 \pm 1.55$ & 0.0748 & $51.9 \pm 15.7$ & 0.0649 \\
& 10 & $1.45 \pm 1.21$ & 0.3588 & $86.9 \pm 27.9$ & $0.0149^{*}$ \\
\hline 7 & 50 & $1.78 \pm 1.72$ & 0.3920 & $163.8 \pm 27.9$ & $0.0011^{*}$ \\
\hline
\end{tabular}

*Significantly different $(\mathrm{p}<0.05)$ from the control.

cytotoxic to $A$. cepa cells or genotoxic to fish erythrocytes, probably because of their low levels of benzene, toluene and xylene. In contrast, wastewater samples from gasoline stations $2,3,5$ and 8 were the most cytotoxic to $A$. cepa because of their high content of aromatic compounds.

In conclusion, our findings indicate that although gasoline station effluents are processed before being discharged into the sewage system, the resulting wastewater still contains toxic compounds. Regular maintenance of the oil/water separation systems can help to reduce the levels of such substances in this wastewater.

\section{Acknowledgments}

This work was supported by the University of Brasília and the Brazilian Agency of Petroleum.

\section{References}

Belfiore NM and Anderson SL (2001) Effects of contaminants on genetic patterns in aquatic organisms: A review. Mutat Res 489:97-122.

Benites CI, Amado LL, Vianna RAP and Martino-Roth MG (2006) Micronucleus test on gas attendants. Genet Mol Res 5:45-54.

Bukvic N, Bavaro P, Elia G, Cassano F, Fanelli M and Guanti G (1998) Sister chromatid exchanges (SCE) and micronucleus (MN) frequencies in lymphocytes of gasoline station attendants. Mutat Res 415:25-33.

Carere A, Antoccia A, Crebelli R, Degrassi F, Fiore M, Iavarone I, Isacchi G, Lagorio S, Leopardi P, Marcon F, et al. (1995) Genetic effects of petroleum fuels: Cytogenetic monitoring of gasoline station attendants. Mutat Res 322:17-26.

Çelik A and Akbas E (2005) Evaluation of sister chromatid exchanges and chromosomal aberration frequencies in periph- eral blood lymphocytes of gasoline station attendants. Ecotox Environ Saf 60:106-112.

Çelik A, Çavas T and Ergene-Gozukara S (2003) Cytogenetic biomonitoring in petrol station attendants: Micronucleus test in exfoliated buccal cells. Mutagenesis 18:417-421.

Environmental Protection Agency (1985) Polynuclear aromatic hydrocarbons: Mechanism, method and metabolism, In: Cooke M and Dennis AJ (eds) American Petroleum Institute. Battelle Press, Columbus, 1464 pp.

Grisolia CK and Cordeiro CMT (2000) Variability in micronucleus induction with different mutagens applied to several species of fish. Genet Mol Biol 23:235-239.

Hayashi M, Ueda T, Uyeno K, Wada K, Kiane, N, Saotorne K, Tanaka N, Takai A, Sasaki YF, Asano N, et al. (1998) Development of genotoxicity assay systems that use aquatic organisms. Mutat Res 399:125-133.

International Program on Chemical Safety (1998) Selected nonheterocyclic aromatic hydrocarbons. In: Hertel RF, Rosner G and Kielhorn J (eds), Environmental Health Criteria 202. World Health Organization, Geneve, 50 pp.

Hooftman RN and Raat WK (1982) Induction of nuclear abnormalities (micronuclei) in the peripheral blood erythrocytes of the eastern mudminnow Umbra pygmaea by ethyl methanesulphonate. Mutat Res 104:147-152.

Hoshima MM, Angelis, DF and Marin-Morales MA (2008) Induction of micronucleus and nuclear alterations in fish (Oreochromis niloticus) by a petroleum refinery effluent. Mutat Res 656:44-48.

Rank J and Nielsen MH (1993) A modified Allium test as a tool in the screening of genotoxicity of complex mixtures. Hereditas 118:49-53.

Santos-Mello R and Cavalcante B (1992) Cytogenetic studies on gas station attendants. Mutat Res 280:285-290.

\section{Associate Editor: Catarina S. Takahashi}

License information: This is an open-access article distributed under the terms of the Creative Commons Attribution License, which permits unrestricted use, distribution, and reproduction in any medium, provided the original work is properly cited. 